(c) American Dairy Science Association, 2005.

\title{
Relationship Between Glucose Transport and Metabolism in Isolated Bovine Mammary Epithelial Cells
}

\author{
C. T. Xiao and J. P. Cant \\ Department of Animal and Poultry Science, University of Guelph, Ontario, Canada, N1G 2W1
}

\section{ABSTRACT}

Glucose transport by isolated bovine mammary epithelial cells involves translocation across the cell membrane into a compartment that exchanges slowly with the bulk cytosol. The significance to glucose metabolism of this compartmentalization was examined by generation, modeling, and analysis of transport and metabolism data. Net uptake of $5 \mathrm{mM}$ 3-O-methyl-D-glucose by isolated bovine mammary epithelial cells was measured at $37^{\circ} \mathrm{C}$. Time-course curves were better fitted by a double exponential equation than a single exponential equation and were subjected to compartmental analysis to obtain glucose transport model parameters. Lactose synthesis and glucose oxidation rates and cellular concentrations of intermediary metabolites, glucose-6phosphate and glucose-1-phosphate, were measured at varied media glucose concentrations. A model that integrates both glucose transport and metabolism underpredicted the rates of lactose synthesis and glucose oxidation by a factor of 3 . To account for the observed glucose use rates, glucose must be available for phosphorylation once translocated across the cell membrane (intermediate compartmentalization of translocated glucose does not exclude access to hexokinase). Metabolic control analysis indicated that, at physiological glucose concentrations, phosphorylation by hexokinase exerts $80 \%$ of the control of glucose metabolism to lactose and $\mathrm{CO}_{2}$, and transport exerts the remaining $20 \%$. (Key words: milk synthesis, mathematical modeling, glucose transport, metabolism)

Abbreviation key: 3-OMG = 3-O-methyl-D-glucose, CCB = cytochalasin B, DMEM = Dulbecco's Modified Eagle's medium, G1P = glucose-1-phosphate, G6P = glucose-6-phosphate, GLUT = glucose transporter, HK = hexokinase, MSPE = mean square prediction error, $\mathbf{r M S P E}=$ square root of the mean square prediction error.

Received October 26, 2004.

Accepted May 2, 2005.

Corresponding author: John Cant; e-mail: jcant@uoguelph.ca.

\section{INTRODUCTION}

A continuous supply of glucose from the blood circulating in the mammary gland is essential to maintain lactation. Up to $85 \%$ of whole-body glucose turnover is directed to the mammary glands for milk synthesis (Bickerstaffe and Annison, 1974). Synthesis of the disaccharide lactose in the Golgi apparatus represents the major fate of glucose metabolism in the mammary epithelial cells, and glucose oxidation facilitates the synthesis of other milk components such as fatty acids (Mepham, 1987). Through osmosis, lactose is the major determinant of milk volume (Holt, 1983). Therefore, its synthesis dictates the milk yield and percentage composition of other components in the milk.

In the lactating mammary epithelial cell, based on the low intracellular concentration of glucose and the similarity between rates of glucose consumption and uptake, it has been suggested that glucose transport from plasma into the cell is rate-limiting to lactose synthesis (Wilde and Kuhn, 1981; Threadgold et al., 1982; Threadgold and Kuhn, 1984). Evidence to the contrary has accumulated. Infusion of glucose into an artery proximal to the mammary glands of lactating cows increased mammary glucose uptake by $40 \%$, but mammary blood flow declined and lactose synthesis was elevated by only 6\% (Cant et al., 2002). Duodenal infusion of 1500 or $2400 \mathrm{~g} / \mathrm{d}$ glucose had little effect on mammary lactose synthesis although intracellular glucose concentration was elevated (Hurtaud et al., 1998; Rigout et al., 2002). Metabolic control analysis (Fell, 1992) provides a methodology to quantitatively assess the degree of control individual enzymes or transporters exert over the flux through a metabolic pathway. Recent applications of control analysis to glucose metabolism in Trypanosoma brucei (Bakker et al., 1999) suggested that transport exerted 30 to $50 \%$ control at $5 \mathrm{~m} M$ glucose. In human skeletal muscle cells, phosphorylation by hexokinase (HK) exerted 15 to $20 \%$ control over glucose metabolic rates (Perriott et al., 2001). Similarly, although glucose supply was the primary factor that regulated glycogen accumulation in skeletal muscle at normal state, glycogen synthase activity also contributed to the control of glycogen accumulation in the fasting state (Ren et al., 1993; Fisher et al., 2002). The relative 
control over glucose metabolism by its transport and phosphorylation has not been determined in bovine mammary epithelial cells.

An appropriate description of glucose transport kinetics, particularly of its reversibility, must be considered for control analysis. Lactating mammary epithelial cells use glucose transporter (GLUT) to move glucose across the basolateral membrane (Zhao et al., 1996). Initial glucose entry rates into mammary epithelial cells measured over a short time interval exhibit Michaelis-Menten saturation kinetics relative to glucose concentration (Threadgold et al., 1982; Xiao and Cant, 2003). However, the intracellular concentration of glucose influences the apparent $\mathrm{K}_{\mathrm{m}}$ and $\mathrm{V}_{\max }$ of entry (Xiao and Cant, 2003), as shown for human erythrocytes (Wheeler and Whelan, 1988; Cloherty et al., 1996). It has been suggested that the effect of intracellular glucose is an artifact of its compartmentalization (Carruthers, 1991; Naftalin and Rist, 1991; Xiao et al., 2004). A compartmental model of symmetric, carrier-mediated translocation of glucose across the plasma membrane into an occlusion space that also exchanges by diffusion with the bulk cytosol can reproduce the anomalous kinetic behavior of initial entry rates in human erythrocytes (Heard et al., 2000) and bovine mammary epithelial cells (Xiao et al., 2004). It has been proposed that the occlusion space is a cage formed by cytoplasmic domains of GLUT1 molecules organized in a homotetramer under the influence of cytosolic ATP (Heard et al., 2000). Whether glucose in the occluded space is available for phosphorylation by HK and subsequent metabolism is unknown. The objectives of this study were to simultaneously measure kinetics of glucose transport and oxidation and lactose synthesis in bovine mammary epithelial cells and, by integrating these separate measures together in simulation models, to estimate the degree of control of glucose transport over glucose metabolism using the equations of metabolic control analysis.

\section{MATERIALS AND METHODS}

\section{Materials}

All chemicals and enzymes were purchased from Sigma-Aldrich (St. Louis, MO) unless otherwise stated. 3-O-Methylglucose (3-OMG; $167 \mathrm{GBq} / \mathrm{mmol} ; 99.8 \%$ ) and D-[U- $\left.{ }^{14} \mathrm{C}\right]$ glucose $(12.0 \mathrm{GBq} / \mathrm{mmol}, 98.7 \%)$ were from Amersham Life Science (Buckinghamshire, UK). The NAD $(\mathrm{P}) \mathrm{H}$ :oxidoreductase (EC 1.6.8.1) and glucose6-phosphate dehydrogenase (EC 1.1.1.49) were supplied by Roche Diagnostics (Laval, Quebec, Canada). Hank's Balanced Salt Solution and Dulbecco's Modified Eagle's medium (DMEM) base were from GibcoBRL (Life Technologies, Burlington, Ontario, Canada).

\section{Cell Preparation}

On 3 separate occasions, epithelial cells were prepared as previously described (Xiao and Cant, 2003) from mammary tissue obtained at slaughter from a lactating Holstein dairy cow producing milk at $15 \mathrm{~kg} /$ d. Minced tissue was digested with $0.1 \%$ (wt/vol) collagenase in Hank's Balanced Salt Solution for 75 min. Cells were collected via centrifugation and washed 3 times with ice-cold PBS. Cells were then resuspended in glucose-deficient DMEM base at a protein concentration of 2 to $4 \mathrm{mg} / \mathrm{mL}$ and stored on ice for 3-OMG accumulation and glucose metabolism experiments. Both sets of experiments were completed within $6 \mathrm{~h}$ of tissue collection. Cell protein was analyzed by the BioRad assay kit using BSA as the standard.

\section{Time Course of Accumulation of 3-OMG by Isolated Cells}

Net uptake of 3-OMG into cells from the 3 cows was measured at $37^{\circ} \mathrm{C}$ by incubating $100 \mu \mathrm{L}$ of cell suspension with $100 \mu \mathrm{L}$ of DMEM base medium containing $10 \mathrm{~m} M$ 3-O-methyl-D-[1- $\left.{ }^{3} \mathrm{H}\right]$ glucose $(10 \mu \mathrm{Ci} / \mathrm{mL})$ for various periods between $15 \mathrm{~s}$ and $30 \mathrm{~min}$. Where cytochalasin B (CCB) effects were examined, CCB was included in the incubation media to give a final concentration of $0.3 \mu M$. At the end of each incubation interval, uptake was terminated by addition of $3 \mathrm{~mL}$ of ice-cold PBS (pH 7.4) containing $20 \mu M$ CCB. Cells were then loaded onto Whatman GF/C filters (Fisher Scientific, Whitby, Ontario, Canada) premoistened with PBS, and mounted on a Millipore vacuum filtration unit. Filters were immediately washed with $30 \mathrm{~mL}$ of ice-cold PBS. Filters were transferred into $20-\mathrm{mL}$ scintillation vials, soaked with $0.5 \mathrm{~mL}$ of water for $30 \mathrm{~min}$. Ten milliliters of scintillation fluid (ICN Pharmaceuticals, Inc., Aurora, $\mathrm{OH}$ ) was then added to each vial. Vials were counted in a Beckman 6000 scintillation counter. Blanks (time zero uptake) were prepared by addition of stopping solution before addition of incubation media containing 3-OMG and radiolabel, followed by immediate wash. Nonspecific binding of radiolabel to filters was monitored by filtration and washing of incubation media alone. Uptakes were measured in triplicate for each time point and from each cow.

\section{Glucose Metabolism}

All incubations were carried out at $37^{\circ} \mathrm{C}$ for $60 \mathrm{~min}$. After prewarming at room temperature for $30 \mathrm{~min}, 200$ $\mu \mathrm{L}$ cell suspensions were mixed with $400 \mu \mathrm{L}$ of DMEM base supplemented with amino acids and different concentrations of glucose to give final glucose concentrations of 0.5 to $10 \mathrm{~m} M$. Where applicable, CCB was in- 
cluded in the media at a final concentration of $0.3 \mu M$. To provide the cells with optimal amino acid precursors for milk protein synthesis, DMEM media was supplemented with free amino acids in the same profile as found in milk protein (Cant et al., 2001). At the end of the 60-min incubation, the entire $600-\mu \mathrm{L}$ cell suspension was immediately frozen at $-20^{\circ} \mathrm{C}$ and stored for analysis of lactose, glucose-6-phosphate $(\mathbf{G 6 P})$, and glucose-1-phosphate (G1P).

Parallel incubations were carried out in $10-\mathrm{mL}$ polypropylene tubes to quantify glucose oxidation. The $\mathrm{CO}_{2}$ production was assayed as described by Lehoux et al. (1997) with modifications. D-[U- $\left.{ }^{14} \mathrm{C}\right]$ Glucose was included in the media at $0.5 \mu \mathrm{Ci}$ per tube. At the initiation of incubation, tubes were sealed with a stopper (Kimble Kontes, Mandel Scientific Co., Guelph, Ontario) into which a polypropylene center well (Kimble Kontes, Mandel Scientific Co.) containing $200 \mu \mathrm{L}$ of freshly prepared $\mathrm{CO}_{2}$-trapping solution (ethanolamine:ethylene glycol, 1:2) was inserted. At the end of the 1-h incubation, $200 \mu \mathrm{L}$ of $30 \%$ (vol $/ \mathrm{vol}$ ) perchloric acid was injected through the stopper into the incubation media with a 16-gauge needle attached to a pipette. After at least $3 \mathrm{~h}$, for complete collection of $\mathrm{CO}_{2}$, center wells were removed from the tubes and stoppers were cut from the rod and placed in $20-\mathrm{mL}$ scintillation vials. One milliliter of water was added to the vial followed by 10 $\mathrm{mL}$ of scintillation fluid (ICN Pharmaceuticals, Inc.) and radioactivity was counted in a Beckman 6000 counter. The $\mathrm{CO}_{2}$-trapping efficiency, assessed by addition of a known quantity of $\mathrm{NaH}^{14} \mathrm{CO}_{3}$ to incubation tubes, was 95 to $103 \%$.

\section{Analysis of Lactose Synthesis and Intermediates}

Lactose, G6P, and G1P were analyzed using bioluminescent methods (Arthur et al., 1989) with modifications. Cell suspensions were homogenized and centrifuged at $8000 \times g$ for $5 \mathrm{~min}$. For lactose analysis, $10 \mu \mathrm{L}$ of supernatant was incubated with $100 \mu \mathrm{L}$ of enzyme reagent for $1 \mathrm{~h}$ at $21^{\circ} \mathrm{C}$. For G6P and G1P analysis, 10 $\mu \mathrm{L}$ of supernatant was incubated with $50 \mu \mathrm{L}$ of enzyme reagent. Twenty microliters of the mixture was added to $200 \mu \mathrm{L}$ of luciferase reagent in round cuvettes (Sarstedt, St-Leonard, QC, Canada), and bioluminescence was read in a BioOrbit 1253 luminometer (BioOrbit Oy, Turku, Finland).

To obtain sufficient G6P and G1P for analysis by bioluminescence, the supernatant following centrifugation of cell suspensions was analyzed. Like lactose, G6P and G1P are secreted from mammary epithelial cells in proportion to their intracellular concentrations (Faulkner et al., 1984; Rigout et al., 2002). The mechanism is likely via the microsomal G6P transporter, which also transports G1P (Leuzzi et al., 2001), is expressed in most cell types (Lin et al., 2000), and exhibits such a high turnover number that steady-state is reached at $22^{\circ} \mathrm{C}$ in $60 \mathrm{~s}$ (Leuzzi et al., 2001). To estimate intracellular G6P and G1P concentrations from measured concentrations in the media after $60 \mathrm{~min}$ of incubation, the relationship between quantity in cell pellets and in supernatant of homogenates from separate pooled incubations was determined. Following a 60-min incubation at 1.0 or $5.0 \mathrm{~m} M$ glucose, cell suspensions were centrifuged at $100 \times g$ for 5 min and pellets were washed 3 times with $3 \mathrm{~mL}$ of ice-cold PBS. Washed cell pellets were deproteinized by addition of $100 \mu \mathrm{L}$ of 1 $M$ perchloric acid, centrifuged at $8000 \times g$ for $5 \mathrm{~min}$, and $80 \mu \mathrm{L}$ supernatant was neutralized by addition of $40 \mu \mathrm{L}$ of neutralizing buffer $(0.5 M$ potassium phosphate $\mathrm{pH} 7.0,2.03 \mathrm{MKOH})$. The sample was centrifuged at $8000 \times g$ for $5 \mathrm{~min}$, and $60 \mu \mathrm{L}$ of supernatant was subjected to G6P and G1P analysis to identify the quantity in cell pellets. Intracellular concentrations of G6P and G1P were calculated by dividing the pellet quantity by intracellular volume estimated from compartmental analysis of the time course of 3-OMG accumulation (see Results section). In 4 determinations, mean \pm SEM concentration of G6P in cell homogenate was $52 \pm 3$ times pellet concentration and homogenate G1P concentration was $44 \pm 2$ times pellet concentration. Intracellular concentrations of G6P and G1P in the glucose metabolism incubations were calculated as G6P and G1P concentrations in cell homogenates divided by factors 52 and 44 , respectively.

\section{Parameter Estimation}

Parameters of transport, oxidation, and lactose synthesis were estimated independently for each process because each process was measured independently, albeit on aliquots of the same cell populations. The transport model of saturable glucose translocation into an occluded space and subsequent diffusion into the bulk cytosol is as previously described (Xiao et al., 2004) and shown in Figure 1A. Values for rate constants $\mathrm{k}_{\mathrm{GlOGII}}$ and $\mathrm{k}_{\mathrm{GIIGlO}}$ and volumes of distribution evol, ivol, and ovol, with and without CCB, were derived from compartmental analysis of the time course of 3-OMG net uptake assuming a closed, sequential 3-pool system and first-order interchanges between pools (Shipley and Clark, 1972). The $\mathrm{K}_{\mathrm{m}}$ of 3-OMG translocation was previously estimated to be $7.88 \mathrm{~m} M$ (Xiao et al., 2004). Cytochalasin B, a noncompetitive inhibitor (Klip, 1982), influences the $\mathrm{V}_{\max }$ but not the $\mathrm{K}_{\mathrm{m}}$ of glucose transport (Bennett et al., 1997). Because both $\mathrm{K}_{\mathrm{m}}$ and $\mathrm{V}_{\max }$ are not simultaneously estimable from a time-course curve where substrate concentration changes little, $\mathrm{K}_{\mathrm{m}}$ was 
A.

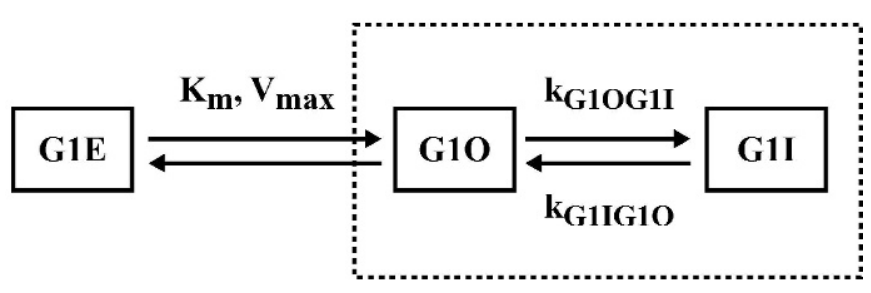

B.

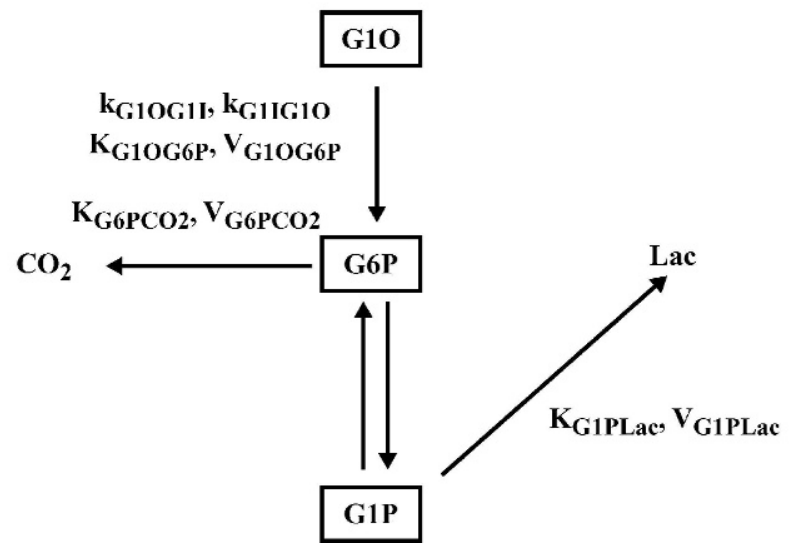

Figure 1. Model structure indicating names of $\mathrm{V}_{\max }, \mathrm{K}_{\mathrm{m}}$, and firstorder rate constants $\mathrm{k}$ fitted from observations. A) Glucose transport model. $\mathrm{GlE}=$ extracellular glucose pool; $\mathrm{GlO}=$ occluded glucose pool; GII = free intracellular glucose pool. Dashed box represents total intracellular glucose. B) Glucose metabolism model. G6P = glucose6-phosphate; G1P = glucose-1-phosphate; Lac = lactose.

fixed at $7.88 \mathrm{~m} M$ from previous concentration-dependence curves, and least-square estimates of the $V_{\max }$ for translocation, with and without CCB, were obtained by iteratively simulating the time course of 3-OMG uptake (Figure 2) with the transport model (Xiao et al., 2004). The iteration routine was a linear search between $\mathrm{V}_{\max }=0$ and $20 \mathrm{nmol} / \mathrm{min}$ with a step size of 0.01 $\mathrm{nmol} / \mathrm{min}$. Kinetic parameters $\mathrm{V}_{\max }$ and $\mathrm{K}_{\mathrm{m}}$ for G1P use in lactose synthesis and G6P use in glucose oxidation (Figure 1B) were estimated by nonlinear least-square regression analysis (SAS Institute, 1999) of product formation rates against substrate concentrations, according to the Michaelis-Menten equation: $v=V_{\max } /(1$ $\left.+K_{m} /[S]\right)$. For all equation fits, mean square prediction error (MSPE) was decomposed into error due to mean bias, due to deviation of the regression from 1 , and due to unexplained variance (Bibby and Toutenburg, 1977). Effects of CCB on parameter values were assessed by $t$-test.

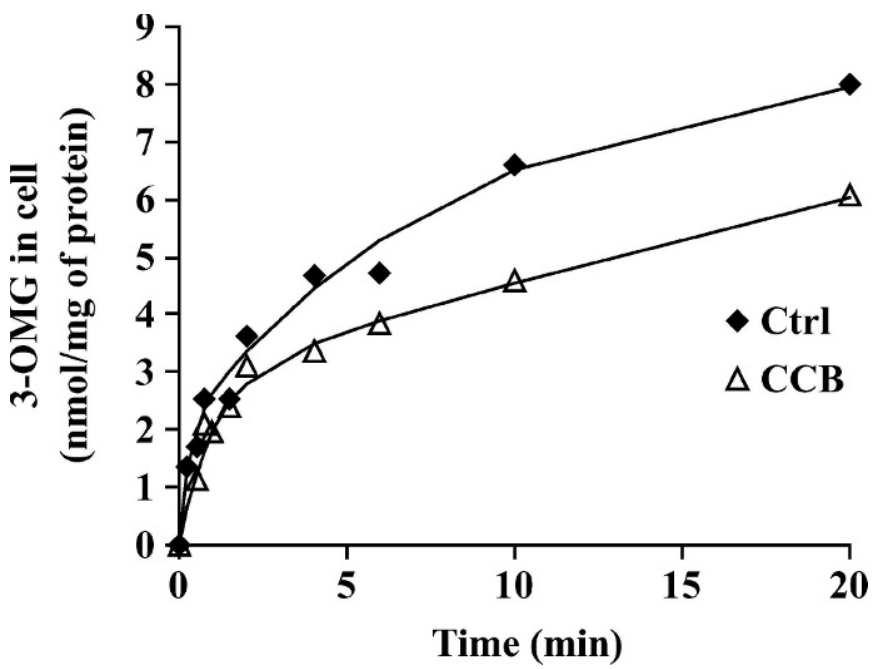

Figure 2. Time course of 3-O-methyl-D-glucose (3-OMG) accumulation in mammary epithelial cells from 1 of 3 cows. Cells were incubated in $5 \mathrm{mM} 3-\mathrm{OMG}$ for varied times at $37^{\circ} \mathrm{C}$ in the absence (control; -) or presence $(\triangle)$ of $0.3 \mu M$ cytochalasin B (CCB). The solid lines were computed by numerical integration using a fourth-order RungeKutta algorithm with the rate constants and fractional distribution volumes determined by compartmental analysis.

\section{Mathematical Simulation}

To test hypotheses of how glucose transport and metabolism are related, the 3-compartment glucose transport model was combined with Michaelis-Menten equations for G6P oxidation and G1P conversion to lactose in candidate mathematical models of mammary glucose use. Kinetic parameters estimated for each cow separately were averaged for model behavior runs. Differential equations describing fluxes in and out of intracellular glucose, G6P and G1P, occluded glucose and extracellular glucose pools were written in Advanced Continuous Simulation Language (ACSL, 1997) for solution and numerical integration with a fourth-order Runge-Kutta algorithm using a step size of $0.05 \mathrm{~min}$.

\section{RESULTS}

\section{Time Course of 3-OMG Net Uptake and ССВ Effects}

Net uptake of 3-OMG by isolated bovine mammary epithelial cells from one cow is illustrated in Figure 2. Presence of $0.3 \mu M$ CCB in the incubation media reduced glucose net uptake $(P<0.05)$. The time-course curve was fitted by a double exponential equation 3OMGt $=2.01\left(1-\mathrm{e}^{-2.712 t}\right)+6.62\left(1-\mathrm{e}^{-0.133 t}\right)$. The square root of the MSPE (rMSPE) was, on average, 10\% of the mean observed uptake with an average of $5.8 \%$ of MSPE due to mean and slope bias. The time-course curve for CCB-treated cells was fitted by 3 -OMGt $=2.86$ $\left(1-\mathrm{e}^{-1.275 \mathrm{t}}\right)+14.23\left(1-\mathrm{e}^{-0.047 \mathrm{t}}\right), \mathrm{rMSPE}=8.2 \%$ of the 
mean with $11 \%$ of MSPE due to mean and slope bias. For both treatments on all 3 cows, a single exponential equation yielded a less satisfactory curve fit, as expressed in rMSPE values of 23 and $20 \%$ of the mean for CCB-untreated and treated cells, respectively, where 39 and $23 \%$ of MSPE, respectively, was due to mean and slope bias.

Compartmental analysis of 3 time-course curves without $\mathrm{CCB}$ yielded the following average $\pm \mathrm{SE}$ rate constants and glucose fractional distribution volumes: $\mathrm{K}_{\mathrm{m}}=7.88 \pm 0.10 \mathrm{mM}, \mathrm{V}_{\max }=9.64 \pm 0.08 \mathrm{nmol} / \mathrm{min}$, $\mathrm{k}_{\mathrm{GlOGII}}=0.29 \pm 0.03 / \mathrm{min}, \mathrm{k}_{\mathrm{GIIGlO}}=0.16 \pm 0.03 / \mathrm{min}, \mathrm{ovol}=$ $0.19 \pm 0.04 \mu \mathrm{L}(34.5 \%)$, and ivol $=0.37 \pm 0.08 \mu \mathrm{L}(65.5 \%)$. Simulations using these parameter values yielded rMSPE of $8 \%$ of the mean observed uptake with an average of $4.7 \%$ of MSPE due to mean and slope bias. Cytochalasin $\mathrm{B}$ reduced $(P<0.05)$ the rate constants to $\mathrm{V}_{\max }=4.50 \pm 0.23 \mathrm{nmol} / \mathrm{min}, \mathrm{k}_{\mathrm{GlOGII}}=0.08 \pm 0.03 /$ min, and $\mathrm{k}_{\mathrm{GlIGlO}}=0.05 \pm 0.04 / \mathrm{min}$. The $\mathrm{K}_{\mathrm{m}}$ was fixed at a previous estimate of $7.88 \pm 0.10 \mathrm{~m} M$ (Xiao et al., $2004)$. Volume of the occluded space was slightly increased by CCB administration (ovol $=0.23 \pm 0.004 \mu \mathrm{L}$ ) but bulk cytosolic ivol was increased to a higher degree with high SE indicating less identifiability (ivol $=0.62$ $\pm 0.34 \mu \mathrm{L}$ ), which resulted in a decreased ovol/ivol ratio compared with the control $(0.35$ vs. $0.53 ; P<0.05)$. Simulations using these parameter values yielded rMSPE of $7.4 \%$ of the mean observed uptake with an average of $6.3 \%$ of MSPE due to mean and slope bias.

\section{Glucose Oxidation, Lactose Synthesis, and Intermediary Metabolites}

Isolated cells synthesized lactose and oxidized glucose at a constant rate for up to $4 \mathrm{~h}$ of incubation (results not shown). Lactose synthesis rates and glucose oxidation rates were measured over 60 min with varied glucose concentrations in the incubation media. Intracellular concentrations of G6P and G1P increased linearly with increased media glucose concentrations while lactose synthesis and glucose oxidation displayed a saturation response (Figure 3). Assuming $286 \mathrm{~g}$ of parenchymal protein in the whole udder (Toerien et al., 2003), these cows producing $15 \mathrm{~kg} / \mathrm{d}$ of milk containing $5 \%$ lactose at slaughter would have been synthesizing lactose at a rate of $320 \mathrm{nmol} / \mathrm{h}$ per $\mathrm{mg}$ of protein. In the current cell preparation, lactose synthesis rate was approximately $55 \mathrm{nmol} / \mathrm{h}$ per $\mathrm{mg}$ of protein at $3 \mathrm{mM}$ glucose, which is 6 -fold slower than in vivo. On average, $15 \%$ of glucose was directed to oxidation, which is similar to the proportion estimated in vivo (Bickerstaffe and Annison, 1974). Cytochalasin B in the incubation media decreased $(P<0.05)$ concentrations of G6P and G1P
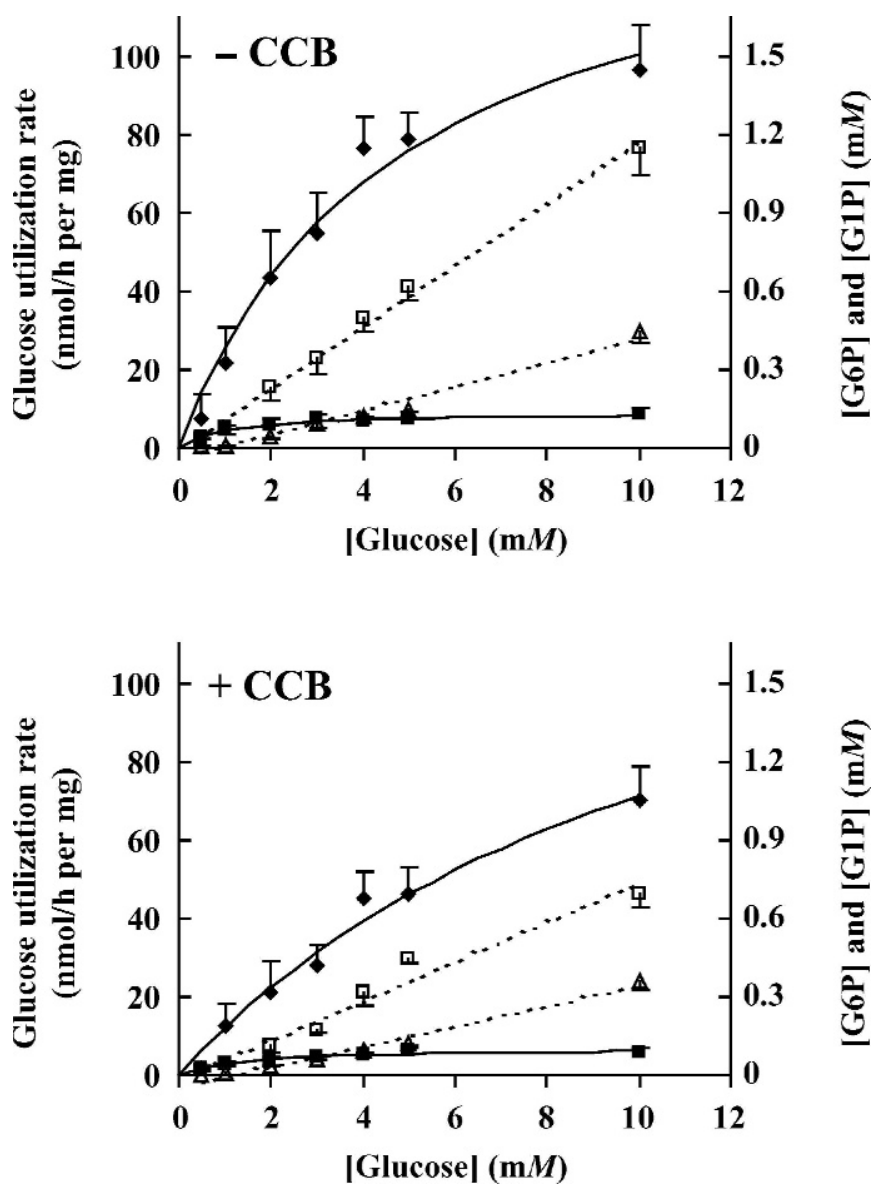

Figure 3. Rates of lactose synthesis $(\bullet)$ and glucose oxidation ( and intracellular concentrations of glucose-6-phosphate (G6P; $\square$ ) and glucose-1-phosphate (G1P; $\triangle$ ) in isolated bovine mammary epithelial cells incubated for 60 min at varying concentrations of extracellular glucose with and without $0.3 \mu M$ cytochalasin $\mathrm{B}(\mathrm{CCB})$ in the media. Each point represents the mean \pm SEM from 3 separate experiments. Dashed lines drawn through the concentration data are linear regression lines. Solid lines drawn through the rate data were generated from the Michaelis-Menten equation with the following parameters: lactose synthesis without CCB $\mathrm{V}_{\max }=148 \mathrm{nmol} / \mathrm{h}$ per $\mathrm{mg}$ of protein, $\mathrm{K}_{\mathrm{m}}=4.74 \mathrm{mM}$; glucose oxidation without $\mathrm{CCB} \mathrm{V}_{\max }=9.20 \mathrm{nmol} / \mathrm{h}$ per $\mathrm{mg}$ of protein, $\mathrm{K}_{\mathrm{m}}=1.12 \mathrm{~m} M$; lactose synthesis with CCB $\mathrm{V}_{\max }=$ $156 \mathrm{nmol} / \mathrm{h}$ per $\mathrm{mg}$ of protein, $\mathrm{K}_{\mathrm{m}}=12.0 \mathrm{mM}$; glucose oxidation with $\mathrm{CCB} \mathrm{V}_{\max }=6.89 \mathrm{nmol} / \mathrm{h}$ per $\mathrm{mg}$ of protein, $\mathrm{K}_{\mathrm{m}}=1.38 \mathrm{~m} M$.

and reduced $(P<0.05)$ rates of glucose oxidation and lactose synthesis (Figure 3).

Observed rates of lactose synthesis and glucose oxidation were plotted against G1P and G6P concentrations, respectively (Figure 4), to obtain Michaelis-Menten parameters for subsequent simulation modeling. Lactose synthesis rates, without and with $\mathrm{CCB}$, were fit with an average rMSPE $=11.2$ and $14.6 \%$ of the observed means, respectively, and an average of $9.2 \%$ of the MSPE due to mean and slope bias. Glucose oxidation rates were fit with an average $\mathrm{rMSPE}=8.0 \%$ of the mean both with and without CCB, where $3.1 \%$ of the 

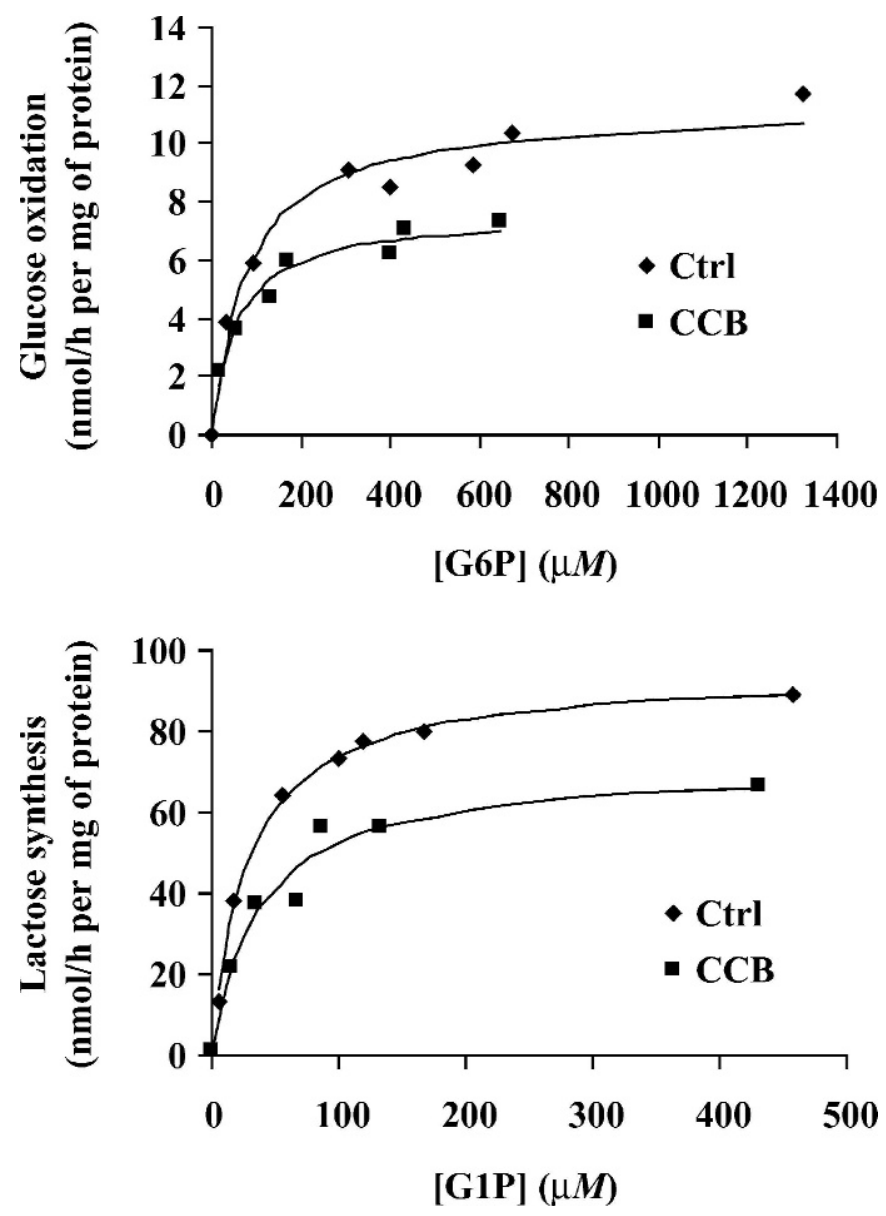

Figure 4. Glucose oxidation (top panel) and lactose synthesis (bottom panel) rates in isolated bovine mammary epithelial cells from 1 of 3 cows in relation to glucose-6-phosphate (G6P) and glucose-1phosphate (G1P) concentrations in the cells. The solid lines drawn through the observed oxidation rates [square root of mean square prediction error $(\mathrm{rMSPE})=7.7 \%$ of the observed mean, mean bias $=$ $0.5 \%$, slope bias $=5.1 \%$, and random disturbance $=94.4 \%$ of mean square prediction error (MSPE)] were computed from the MichaelisMenten equation: control, $\mathrm{K}_{\mathrm{m}}=79.3 \mu M, \mathrm{~V}_{\max }=11.3 \mathrm{nmol} / \mathrm{h}$ per $\mathrm{mg}$ of protein; cytochalasin $\mathrm{B}(\mathrm{CCB}), \mathrm{K}_{\mathrm{m}}=55.2 \mu M, \mathrm{~V}_{\max }=7.62 \mathrm{nmol} / \mathrm{h}$ per $\mathrm{mg}$ of protein. The solid lines drawn through the observed lactose synthesis rates $(\mathrm{rMSPE}=2.4 \%$ of the observed mean, mean bias $=$ $2.6 \%$, slope bias $=17.3 \%$, and random disturbance $=80.1 \%$ of MSPE) were computed from the Michaelis-Menten equation: control, $\mathrm{K}_{\mathrm{m}}=$ $28.3 \mu M, \mathrm{~V}_{\max }=94.7 \mathrm{nmol} / \mathrm{h}$ per $\mathrm{mg}$ of protein; CCB, $\mathrm{K}_{\mathrm{m}}=36.4 \mu M$, $\mathrm{V}_{\max }=93.5 \mathrm{nmol} / \mathrm{h}$ per $\mathrm{mg}$ of protein.

MSPE, respectively, were due to mean and slope bias. According to a $t$-test, neither $\mathrm{V}_{\max }$ nor $\mathrm{K}_{\mathrm{m}}$ for either process was affected $(P>0.1)$ by CCB addition.

\section{Simulation Models of Glucose Transport and Metabolism}

A model to integrate measured kinetics of glucose transport and metabolism is illustrated in Figure 5. The 3-compartment model of glucose transport by isolated

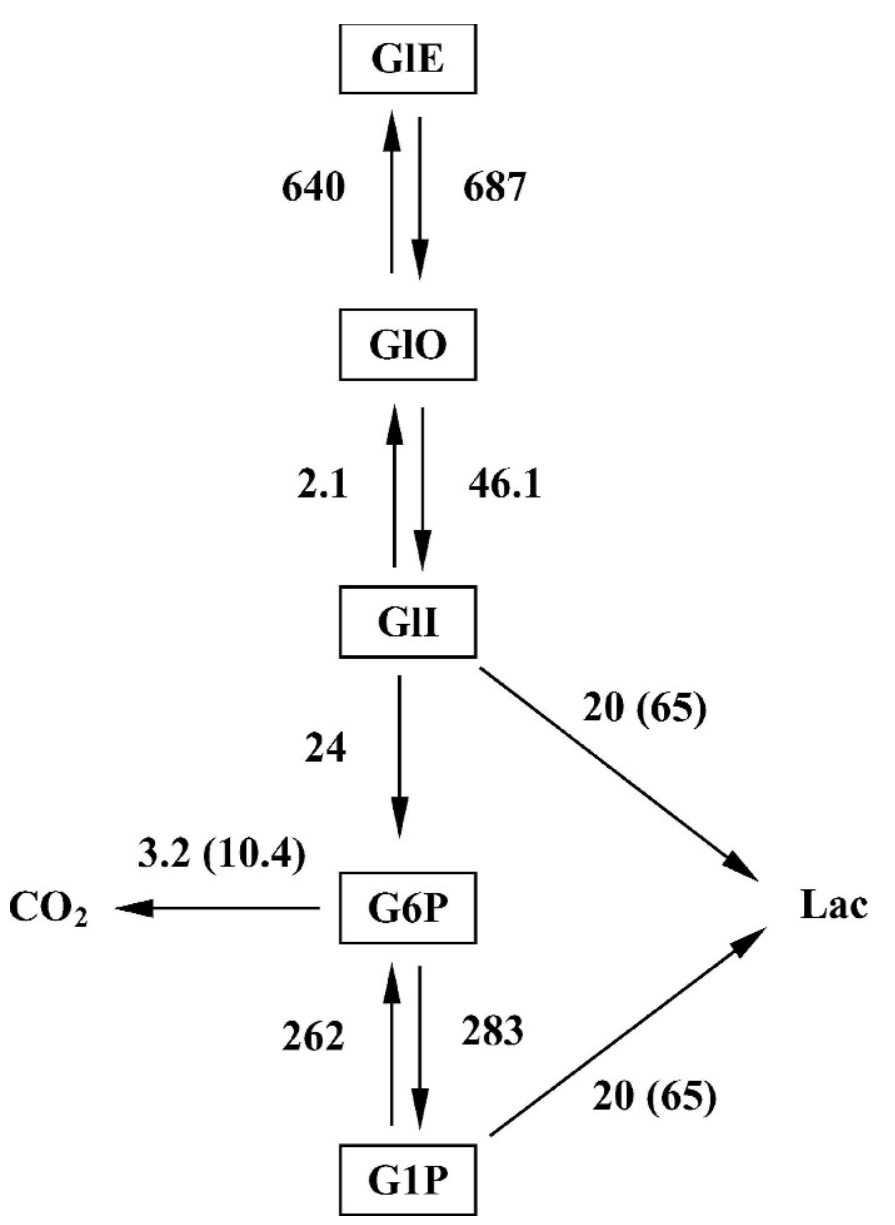

Figure 5. Metabolic fluxes simulated from a 3-compartment transport model. $\mathrm{K}_{\mathrm{m}}$ and $\mathrm{V}_{\max }$ for phosphorylation were $1 \mathrm{~m} M$ and 0.81 $\mathrm{nmol} / \mathrm{min}$, respectively. Values for other parameters were as listed in Table 1 . Fluxes ( $\mathrm{nmol} / \mathrm{h}$ per $\mathrm{mg}$ of protein) are reported as averages over the first $60 \mathrm{~min}$ of incubation and were calculated with cell protein of $0.325 \mathrm{mg}$ and extracellular glucose concentration of $5 \mathrm{mM}$. Values for glucose-6-phosphate (G6P) oxidation and lactose synthesis in parentheses are observed fluxes. $\mathrm{GlE}=$ Extracellular glucose; $\mathrm{GlO}=$ occluded glucose; GII = intracellular glucose; G1P = glucose-1phosphate.

bovine mammary epithelial cells (Xiao et al., 2004) was used. The ultimate step in lactose synthesis is the intraGolgi transfer of the galactose moiety of UDP-galactose, derived from G1P, onto free glucose. Individual steps of the pathways of lactose synthesis and glucose oxidation were aggregated so that the metabolism model consisted of phosphorylation of intracellular glucose to $\mathrm{G} 6 \mathrm{P}$, oxidation of $\mathrm{G} 6 \mathrm{P}$ to $\mathrm{CO}_{2}$, equilibrium between $\mathrm{G} 6 \mathrm{P}$ and G1P, and lactose synthesis from G1P and intracellular free glucose. In this model, it was assumed that only glucose in the true intracellular space would proceed for metabolism through phosphorylation by HK.

Model equations are presented in the Appendix and parameters are summarized in Tables 1 and 2. Michae- 
Table 1. Symbols used in the models shown in Figures 1, 5, 6, 7, and Appendix.

\begin{tabular}{lll}
\hline Symbol $^{1}$ & Description & Unit \\
\hline prot & Total cell protein & $\mathrm{mg}$ \\
evol & Extracellular volume & $\mu \mathrm{L}$ \\
ovol & Occluded volume & $\mu \mathrm{L}$ \\
ivol & Intracellular volume & $\mu \mathrm{L}$ \\
$\mathrm{GlE}$ & Extracellular glucose & $\mathrm{nmol}$ \\
$\mathrm{GlO}$ & Occluded glucose & $\mathrm{nmol}$ \\
$\mathrm{GlI}$ & Intracellular glucose & $\mathrm{nmol}$ \\
$\mathrm{G} 6 \mathrm{P}$ & Glucose-6-phosphate pool & $\mathrm{nmol}$ \\
$\mathrm{G} 1 \mathrm{P}$ & Glucose-1-phosphate pool & $\mathrm{nmol}$ \\
$\mathrm{Lac}$ & Lactose & $\mathrm{nmol}$ \\
$\mathrm{CO} 2$ & CO & $\mathrm{nmol}$ \\
$\mathrm{k}_{\mathrm{ij}}$ & First-order rate constant for i-j transaction & $/ \mathrm{min}$ \\
$\mathrm{K}_{\mathrm{ij}}$ & Michaelis-Menten constant for i-j transaction & $\mathrm{m} M$ \\
$\mathrm{~V}_{\mathrm{ij}}$ & Maximal velocity for i-j transaction & $\mathrm{nmol} / \mathrm{min}$ \\
\hline
\end{tabular}

${ }^{1}$ Subscript letters $\mathrm{i}$ and $\mathrm{j}$ represent the entity of 2 different pools.

lis-Menten equations were used to describe glucose phosphorylation, oxidation, and lactose synthesis. Parameters for glucose transport were obtained from the 3-OMG accumulation time-course curves (Figure 2). It was implicitly assumed that parameters of $3-\mathrm{OMG}$ transport could be directly applied to glucose. Although the kinetics of 3-OMG uptake by mammary secretory cells have not been compared with those of D-glucose uptake, in the human erythrocyte the $\mathrm{K}_{\mathrm{m}}$ for zero-trans entry was $0.38 \pm 0.13$ and $0.46 \pm 0.09 \mathrm{~m} M$ for the 2 sugars, respectively (Helgerson and Carruthers, 1989). Values of the $\mathrm{K}_{\mathrm{m}}$ for infinite-trans entry of 3-OMG and glucose into erythrocytes were $1.57 \pm 0.10$ and 2.19 $\pm 0.36 \mathrm{mM}$, respectively (Helgerson and Carruthers, 1989). The similarity in binding affinities suggests that the 3-OMG kinetics measured here can be used as approximations of glucose kinetics. Parameters of lactose

Table 2. Values of the parameters used in simulations with values for the models shown in Figures 1, 6, 7, and Appendix.

\begin{tabular}{|c|c|c|c|}
\hline \multirow[b]{2}{*}{ Parameter } & \multirow[b]{2}{*}{ Unit } & \multicolumn{2}{|c|}{ Values $^{1}$} \\
\hline & & - Cytochalasin B & + Cytochalasin B \\
\hline prot & $\mathrm{mg}$ & $0.33(0.02)$ & $0.35(0.001)$ \\
\hline evol & $\mu \mathrm{L}$ & $199.44(0.11)$ & $199.15(0.34)$ \\
\hline ovol & $\mu \mathrm{L}$ & $0.19(0.04)$ & $0.23(0.004)$ \\
\hline ivol & $\mu \mathrm{L}$ & $0.37(0.08)$ & $0.62(0.34)$ \\
\hline $\mathrm{k}_{\mathrm{GlOGII}}$ & $/ \min$ & $0.29(0.02)$ & $0.08(0.03)$ \\
\hline $\mathrm{k}_{\text {GIIGIO }}$ & $/ \mathrm{min}$ & $0.16(0.03)$ & $0.05(0.04)$ \\
\hline $\mathrm{k}_{\mathrm{G} 6 \mathrm{PG} 1 \mathrm{P}}$ & $/ \min$ & 75 & 75 \\
\hline $\mathrm{k}_{\mathrm{G} 1 \mathrm{PG} 6 \mathrm{P}}$ & $/ \mathrm{min}$ & 400 & 400 \\
\hline $\mathrm{K}_{\mathrm{GlEGIO}}$ & $\mathrm{m} M$ & $7.88(0.10)$ & $7.88(0.10)$ \\
\hline $\mathrm{V}_{\text {GIEGIO }}$ & $\mathrm{nmol} / \mathrm{min}$ & $9.64(0.08)$ & $4.50(0.23)$ \\
\hline $\mathrm{V}_{\mathrm{GlOG} G \mathrm{P}}$ & $\mathrm{nmol} / \mathrm{min}$ & 0.85 & 0.85 \\
\hline $\mathrm{K}_{\mathrm{GlOG} 6 \mathrm{P}}$ & $\mathrm{m} M$ & 3.5 & 3.5 \\
\hline $\mathrm{V}_{\mathrm{G} 6 \mathrm{PCO} 2}$ & $\mathrm{nmol} / \mathrm{min}$ & $0.07(0.02)$ & $0.07(0.02)$ \\
\hline $\mathrm{K}_{\mathrm{G} 6 \mathrm{PCO} 2}$ & $\mathrm{~m} M$ & $0.08(0.02)$ & $0.08(0.02)$ \\
\hline $\mathrm{V}_{\mathrm{G} 1 \mathrm{PLac}}$ & $\mathrm{nmol} / \mathrm{min}$ & $0.64(0.16)$ & $0.64(0.16)$ \\
\hline $\mathrm{K}_{\mathrm{G1PLac}}$ & $\mathrm{m} M$ & $0.06(0.03)$ & $0.06(0.03)$ \\
\hline
\end{tabular}

${ }^{1}$ Values in parentheses indicate SE of multiple estimates. synthesis and glucose oxidation were obtained from the fits against G1P and G6P concentrations, respectively (Figure 4). Parameters for glucose phosphorylation in lactating rat mammary acini were reported as $\mathrm{K}_{\mathrm{m}}=1$ $\mathrm{m} M$ and $\mathrm{V}_{\max }=2.5 \mathrm{nmol} / \mathrm{min}$ per $\mathrm{mg}$ of protein (Threadgold et al., 1982). At $0.325 \mathrm{mg}$ of protein in the incubation, this $\mathrm{V}_{\max }=0.81 \mathrm{nmol} / \mathrm{min}$. Rate of use of free glucose for lactose synthesis was set stoichiometrically equal to the rate of G1P use for lactose synthesis. Conversion between G6P and G1P was described by firstorder rate constants set high (100 to 300 times that for glucose phosphorylation) to approximate equilibrium between these 2 metabolites.

To illustrate consequences of the hypothetical metabolic flow structure, the predicted steady-state flows of glucose metabolites after 60 min of simulated incubation at a single initial extracellular glucose concentration of $5 \mathrm{~m} M$ were presented (Figure 5). With the original model, predicted lactose yield and glucose oxidation rates were one-third of the observed. The bottleneck in use of glucose was at the exchange between occluded and true intracellular compartments. Translocation of glucose from the extracellular space, measured in the time course experiments, was approximately 10 times the net sequestration rate, measured in the metabolism experiments, but exchange into the intracellular space was $1 / 15$ of the translocation rate.

The model was therefore modified to allow phosphorylation of occluded glucose by HK (Figure 6). Because affinity of HK to occluded glucose may be different than to cytosolic glucose, instead of using published values from mammary homogenates, least-square estimates of Michaelis-Menten parameters for glucose phosphorylation were obtained by iteratively calculating the residual sum of squares between simulated and observed glucose oxidation and lactose synthesis rates in the 60-min incubations of mammary epithelial cells with varied media glucose concentrations. It was found that, to avoid bias in whether phosphorylated glucose was directed to $\mathrm{CO}_{2}$ or lactose, the first-order rate constants of the G6P:G1P equilibrium also had to be changed. The approach to least squares was accomplished by inspection of fit results and not by a software routine. The final values for these parameters were $\mathrm{K}_{\mathrm{GlOG} 6 \mathrm{P}}=$ $3.5 \mathrm{~m} M, \mathrm{~V}_{\mathrm{GlOG} 6 \mathrm{P}}=0.85 \mathrm{nmol} / \mathrm{min}, \mathrm{k}_{\mathrm{G} 6 \mathrm{PG} 1 \mathrm{P}}=75 / \mathrm{min}$, and $\mathrm{k}_{\mathrm{G} 1 \mathrm{PG} 6 \mathrm{P}}=400 / \mathrm{min}$ (Table 2). The apparent $\mathrm{K}_{\mathrm{m}}$ for glucose phosphorylation was previously estimated at 1 $\mathrm{m} M$ in mammary homogenates (Threadgold et al., 1982 ) and $0.1 \mathrm{mM}$ in L6 myotubes (Whitesell et al., 2003).

The modified model simulated the rates of glucose oxidation and lactose synthesis observed at varied extracellular glucose concentrations with $\mathrm{rMSPE}=6.6$ and $11 \%$, respectively, of the observed means. The pro- 


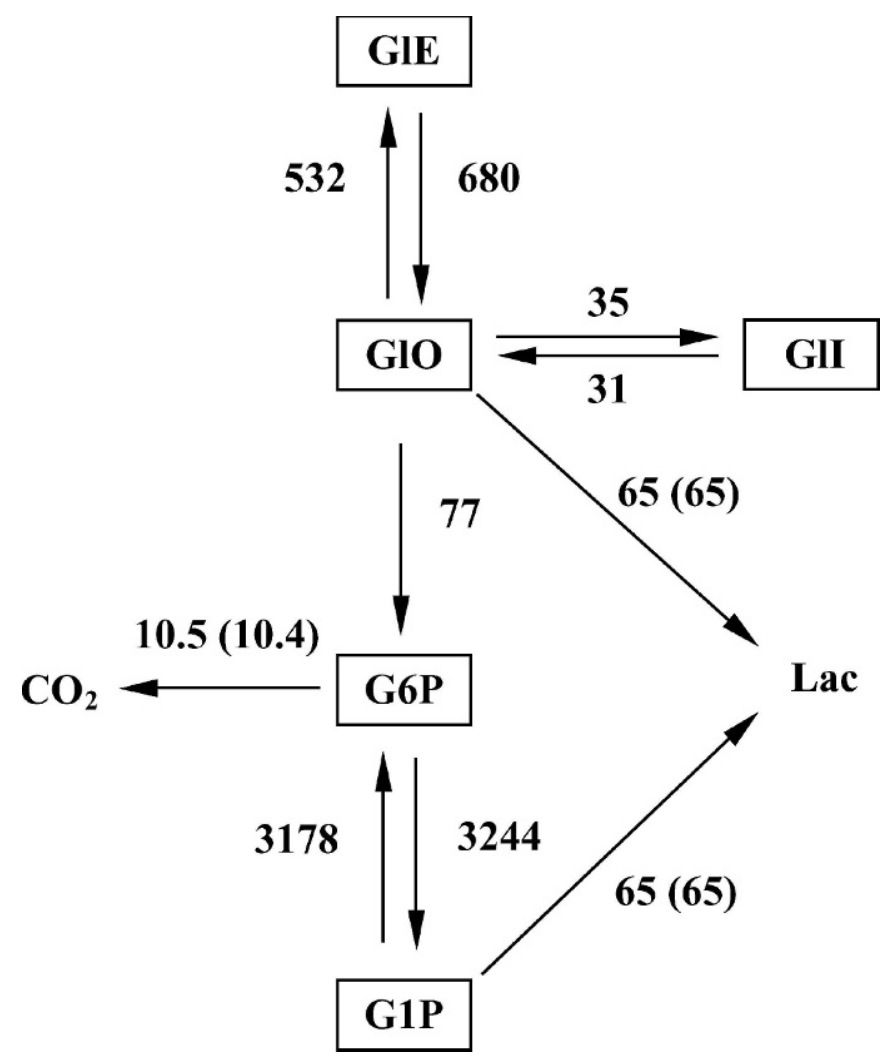

Figure 6. Metabolic fluxes simulated from a model that allows hexokinase access to occluded glucose. $\mathrm{K}_{\mathrm{m}}$ and $\mathrm{V}_{\max }$ for glucose phosphorylation was $3.5 \mathrm{mM}$ and $0.85 \mathrm{nmol} / \mathrm{min}$, respectively. Fluxes (nmol/h per mg of protein) are reported as averages over the first 60 min of incubation and were calculated with cell protein of $0.33 \mathrm{mg}$ and extracellular glucose concentration of $5 \mathrm{mM}$. Values for glucose6-phosphate (G6P) oxidation and lactose synthesis in parentheses are observed fluxes. GlE = Extracellular glucose; $\mathrm{GlO}=$ occluded glucose; GlI = intracellular glucose; G1P = glucose-1-phosphate .

portion of error due to random disturbance was 90 and $99 \%$, due to mean bias was 1.9 and $0 \%$, and due to slope bias was 8.1 and $0.5 \%$ for glucose oxidation and lactose synthesis, respectively. Predicted fluxes at $5 \mathrm{mM}$ glucose are shown in Figure 6. The effects of CCB perturbation were simulated using the model shown in Figure 6 and Table 1 with the average glucose translocation $\mathrm{V}_{\max }$ from $+\mathrm{CCB}$ incubations (Figure 2) of $4.50 \mathrm{nmol} /$ min. At $5 \mathrm{~m} M$ glucose, the model simulated a reduced glucose oxidation and lactose synthesis compared with the control (Figure 7). Rates of glucose oxidation and lactose synthesis across the range of extracellular glucose concentrations used were simulated with rMSPE = 35 and $20 \%$ of the observed mean, respectively.

\section{DISCUSSION}

\section{Effects of Intracellular Compartmentalization on Glucose Metabolism}

The primary glucose transporter expressed in bovine mammary glands during lactation is GLUT1 (Zhao et

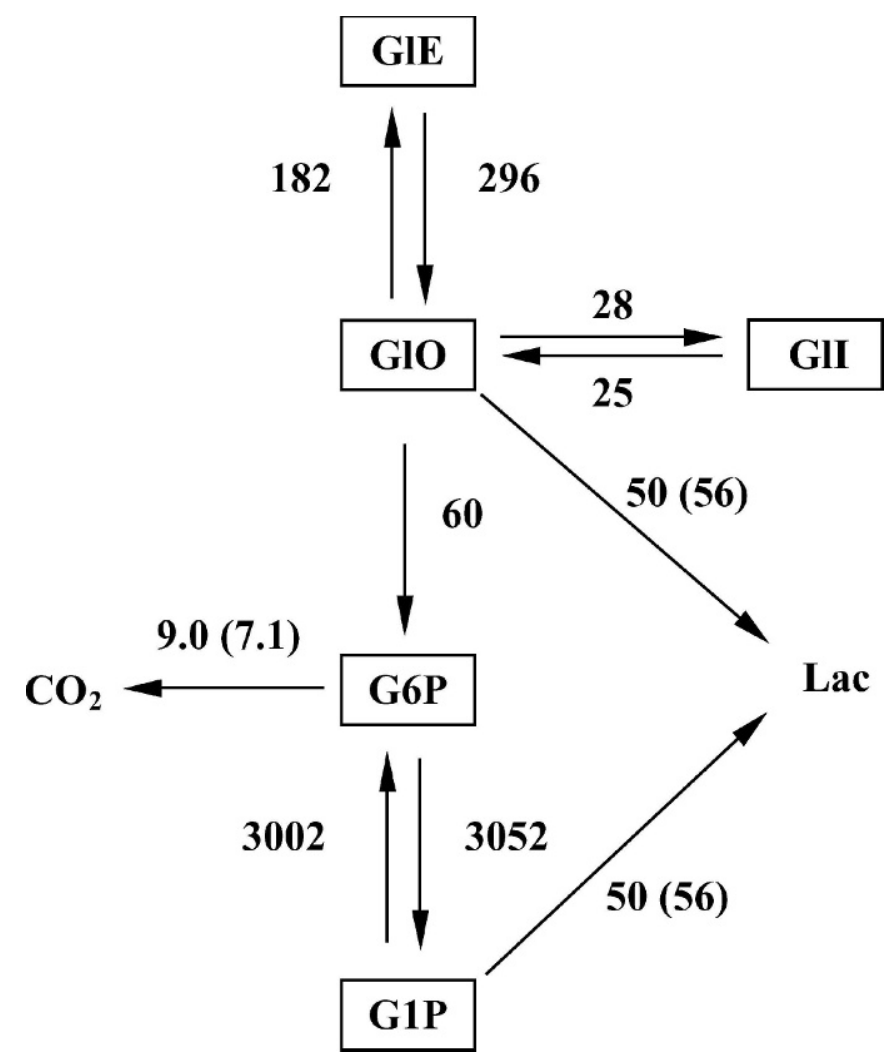

Figure 7. Metabolic fluxes simulated from a model that allows hexokinase access to occluded glucose: Cytochalasin B (CCB) effects. $\mathrm{K}_{\mathrm{m}}$ and $\mathrm{V}_{\max }$ for glucose phosphorylation was $3.5 \mathrm{mM}$ and $0.85 \mathrm{nmol} /$ $\mathrm{min}$. Fluxes (nmol/h per $\mathrm{mg}$ of protein) are reported as averages over the first $60 \mathrm{~min}$ of incubation and were calculated with cell protein of $0.35 \mathrm{mg}$ and extracellular glucose concentration of $5 \mathrm{mM}$. Values for glucose-6-phosphate (G6P) oxidation and lactose synthesis in parentheses are observed fluxes. $\mathrm{GlE}=$ Extracellular glucose; $\mathrm{GlO}=$ occluded glucose; GII = intracellular glucose; G1P = glucose-1-phosphate. See Appendix for mathematical description of the model.

al., 1996). Although Na-dependent glucose transporter SGLT1 and GLUT12 protein and mRNA have been detected in mammary cell membranes, their localization and physiological significance remain unclear (Macheda et al., 2003; Zhao et al., 1999). Despite detailed glucose transport kinetic studies in human erythrocytes in which GLUT1 is most abundantly expressed, there is a paucity of information on bidirectional glucose transport kinetics in mammary epithelial cells and their significance to milk synthesis. The anomalies of glucose transport in human erythrocytes, including asymmetric transport across the cell membrane, are well documented (Regen and Tarpley, 1974; Baker and Naftalin, 1979). These characteristics have prompted several hypotheses to explain the mechanism of GLUT1-mediated glucose transport (Widdas, 1952; Eilam and Stein, 1974; Carruthers, 1991). According to the latest hypothesis (Heard et al., 2000), glucose trans- 
port into human erythrocytes is the sum of 2 serial processes: glucose translocation and release into cytosol. Glucose is translocated across the cell membrane by a GLUT1 homotetramer. Upon binding of ATP to GLUT1 on the cytosolic side, the 4 GLUT1 molecules form a cage that occludes the posttranslocated glucose. Glucose molecules inside the cage can be recycled back to the extracellular space, bound to sites within the cage, or released into the cytosol. This model successfully accounted for the anomalous kinetic behavior and ATP effects in human erythrocytes (Heard et al., 2000). A similar model taking into account compartmentalization of posttranslocated glucose, was capable of simulating time course and intracellular and extracellular concentration dependence of 3-OMG transport by isolated bovine mammary epithelial cells (Xiao et al., 2004). Likewise, time course of intracellular 3-OMG accumulation in the current experiment was better fitted with a double exponential equation than with a single exponential equation, indicating the presence of 2 intracellular compartments.

The glucose transport model of Heard et al. (2000) implies that glucose molecules are occluded in transit space before they enter the cytosol where enzymes responsible for metabolism are located. However, the consequence of this hypothesis for mammary glucose transport was a severely underpredicted rate of lactose synthesis and glucose oxidation (Figure 5). To reconcile the observed rates of glucose use and 3-OMG compartmentalization in the present study, glucose occluded in the cage would have to be available for metabolism, the first step of which is phosphorylation by HK. In other words, the suggested compartmentalization of posttranslocated glucose does not exclude access to HK. The time course and anomalous kinetics of glucose transport in erythrocytes have been interpreted as evidence of an unstirred layer immediately below the cell membrane (Naftalin et al., 1985). An unstirred layer of glucose, as opposed to an occlusion cage, would account for the following observations: the inclusion of an intermediate compartment following translocation, the relatively large occlusion volume, and the availability of glucose in this volume for phosphorylation. In human erythrocyte ghosts double stained for GLUT1 and HK I, colocalization of the 2 proteins was observed and more than a quarter of total cellular HK I was found to be associated with the cell membrane (Cloherty et al., 1995). It also has been suggested that the glucose transporter in rat thymocytes is coupled with HK on the endofacial surface of the cell membrane (Naftalin and Rist, 1989). Furthermore, to explain intracellular glucose phosphorylation kinetics, HK activity in L6 myotubes has been proposed to be restricted to 1 of 2 intracellular glucose compartments which is served by glucose transporters and comprises $15 \%$ of cell volume (Whitesell et al., 2003). The modified model in Figures 6 and 7 depicts this same compartmentalization of intracellular glucose and HK access in mammary epithelial cells.

\section{Control of Glucose Metabolism in Bovine Mammary Epithelial Cells}

It has been suggested that transmembrane transport of glucose is the rate-limiting step for its metabolism (Kahn, 1992; Ren et al., 1993). In mammary epithelial cells, glucose transport has been suggested to be rate limiting to lactose synthesis based on observations of intracellular glucose concentrations below the $\mathrm{K}_{\mathrm{m}}$ for transport into Golgi vesicles (Wilde and Kuhn, 1981). However, a low concentration by itself gives no indication of how rapidly intracellular glucose can be replenished from an extracellular source and thereby influence rate of downstream use. Metabolic control analysis (Fell, 1992) is particularly suited to the task by defining the strength of control points in metabolic pathways with sensitivity parameters called flux control coefficients. A flux control coefficient is a quantitative description of how much the flux through an entire pathway is influenced by a change in activity of each component in the pathway. The sum of all control coefficients in a pathway is equal to 1.0. Using metabolic control analysis, it was demonstrated that glucose transport exerts only part of the total control over glucose metabolism in skeletal muscle cells (Perriott et al., 2001; Fisher et al., 2002; Whitesell et al., 2003), for example. Using the modified model of mammary glucose use, flux control coefficients for glucose transport, phosphorylation and subsequent metabolism were calculated by dividing the fractional change of simulated lactose synthesis rate by a minute fractional change $(0.3 \%)$ in the $V_{\max }$ for each step shown in Figure 7. At a physiological glucose concentration of $3 \mathrm{~m} M$, control of lactose synthesis was shared by, although not evenly distributed between, glucose transport and phosphorylation (Figure 8). Transport exerted $20 \%$ of the control and phosphorylation was predominant at around $80 \%$. The effect of glucose supply on the distribution of control between transport and phosphorylation (Figure 8) indicates that inclusion of the transport inhibitor CCB in the incubation media should have a stronger effect on metabolism at lower glucose concentrations. Indeed, the kinetics of lactose synthesis in relation to medium glucose concentration supports this prediction in that the $\mathrm{V}_{\max }$ was affected little by CCB but the $\mathrm{K}_{\mathrm{m}}$ doubled (Figure 3). In addition, although glucose transport was reduced by $53 \%$ because of CCB inclusion (glucose transport $\mathrm{V}_{\max }$ of $4.50 \mathrm{vs} .9 .64 \mathrm{nmol} / \mathrm{min}, P<0.05$ ), lactose synthesis was only reduced by $14 \%$ (lactose synthesis rate of 56 


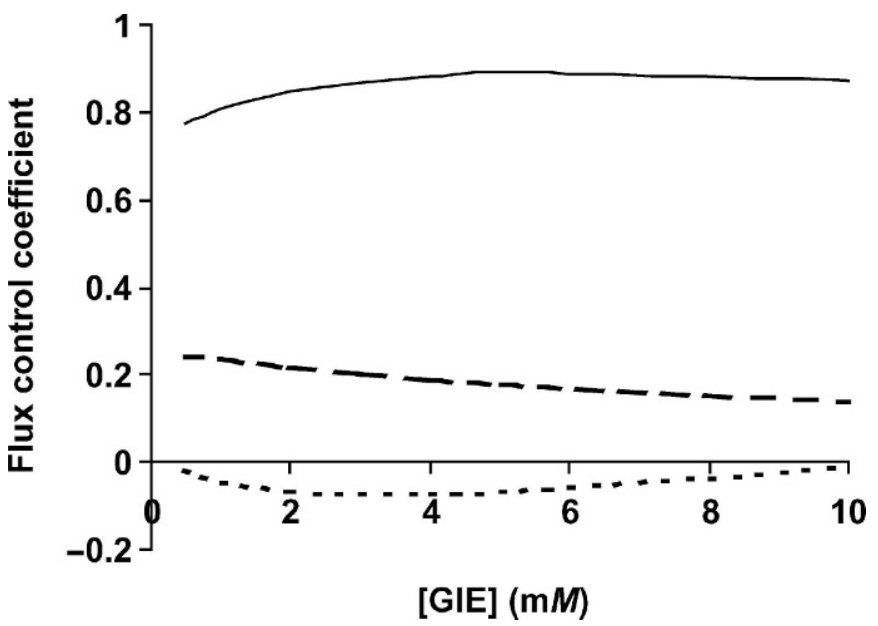

Figure 8. Calculated flux control coefficients for glucose transport (dashed line), phosphorylation (solid line), and sum of remaining steps in lactose synthesis and glucose oxidation (dotted line) over a range of extracellular glucose (GlE) concentrations. The coefficients were calculated from the fractional change in lactose synthesis rate attributed to a minute change $(0.3 \%)$ in the $V_{\max }$ values shown in Table 1.

vs. $65 \mathrm{nmol} / \mathrm{h}$ per $\mathrm{mg}$ of protein). The sum of flux control coefficients for $\mathrm{HK}$ and transport was close to 1, which implies that control on metabolism by steps after phosphorylation was minor. Control of glucose oxidation flux was similarly distributed among GLUT1, HK, and downstream elements. This distribution of control might explain the lack of close correlation between blood glucose concentrations and net glucose use by the mammary glands of the lactating cow in vivo (Cant et al., 1993). In the lactating goat, glucose uptake was more strongly associated with metabolic activity of the mammary glands than with extracellular glucose concentrations (Nielsen et al., 2001).

Because we had no direct measures of the kinetics in these cells, the transport of cytosolic glucose into Golgi vesicles where lactose synthesis takes place was not considered explicitly in any of the candidate simulation models. Rather, Golgi transport was aggregated with the epimerization reactions between G1P and lactose. In simulations (not shown) where the flux from $\mathrm{GlO}$ to lactose was given a $\mathrm{V}_{\max }$ equal to $\mathrm{V}_{\mathrm{G} 1 \mathrm{PLac}}$ and a $\mathrm{K}_{\mathrm{m}}$ of $1.5 \mathrm{mM}$, representing Golgi transport (Wilde and Kuhn, 1981), the control coefficient for the HK reaction was actually elevated by approximately $5 \%$. Thus, the conclusion that HK exerts the majority of control over glucose use remained.

\section{CONCLUSIONS}

Glucose transport across the plasma membrane of bovine mammary epithelial cells appears to involve translocation into an intracellular compartment to which HK has access. The affinity and maximal activity of HK are such that it exerts $80 \%$ of the control of glucose metabolism to lactose and $\mathrm{CO}_{2}$ and transport exerts the remaining 20\%. Strategies to engineer a greater or lesser daily milk yield of cows should thus focus on manipulating $\mathrm{HK}$ activity.

\section{ACKNOWLEDGMENTS}

We thank Linda Trouten-Radford for technical assistance. Thanks are extended to Angela Fairfield and Bev Livingston (Elora Dairy Research Station) for providing the animals, Chris Haworth and Glenn Snider (Meat Laboratory) for tissue sampling, and Bill Szkotnicki for computer maintenance. This work was funded by Agribrands Purina, Ltd., NSERC Canada, and the Ontario Ministry of Agriculture and Food.

\section{REFERENCES}

ACSL. 1997. Advanced Continuous Simulation Language User's Guide. MGA Software, ed. Concord, MA.

Arthur, P. G., J. C. Kent, and P. E. Hartmann. 1989. Microanalysis of the metabolic intermediates of lactose synthesis in human milk and plasma using bioluminescent methods. Anal. Biochem. 176:449-456.

Baker, G. F., and R. J. Naftalin. 1979. Evidence of multiple operational affinities for D-glucose inside the human erythrocyte membrane. Biochim. Biophys. Acta 550:474-484.

Bakker, B. M., M. C. Walsh, B. H. ter Kuile, F. I. Mensonides, P. A. Michels, F. R. Opperdoes, and H. V. Westerhoff. 1999. Contribution of glucose transport to the control of the glycolytic flux in Trypanosoma brucei. Proc. Natl. Acad. Sci. USA 96:10098-10103.

Bennett, B. L., M. R. Grigor, and C. G. Prosser. 1997. Glucose transport in a murine mammary epithelial cell line. Biochem. Mol. Biol. Int. 42:315-323.

Bibby, J., and H. Toutenburg. 1977. Prediction and improved estimation in linear models. Wiley, Chichester, New York, NY.

Bickerstaffe, R., and E. F. Annison. 1974. The metabolism of glucose, acetate, lipids and amino acids in lactating dairy cows. J. Agric. Sci. 82:71-85.

Cant, J. P., E. J. DePeters, and R. L. Baldwin. 1993. Mammary uptake of energy metabolites in dairy cows fed fat and its relationship to milk protein depression. J. Dairy Sci. 76:2254-2265.

Cant, J. P., D. R. Trout, F. Qiao, and B. W. McBride. 2001. Milk composition responses to unilateral arterial infusion of complete and histidine-lacking amino acid mixtures to the mammary glands of cows. J. Dairy Sci. 84:1192-1200.

Cant, J. P., D. R. Trout, F. Qiao, and N. G. Purdie. 2002. Milk synthetic response of the bovine mammary gland to an increase in the local concentration of arterial glucose. J. Dairy Sci. 85:494-503.

Carruthers, A. 1991. Mechanisms for the facilitated diffusion of substrates across cell membranes. Biochemistry 30:3898-3906.

Cloherty, E. K., K. S. Heard, and A. Carruthers. 1996. Human erythrocyte glucose transport is incompatible with available carrier models. Biochemistry 35:10411-10421.

Cloherty, E. K., L. A. Sultzman, R. J. Zottola, and A. Carruthers. 1995. Sugar transport is a multistep process. Evidence for cytosolic sugar binding sites in erythrocytes. Biochemistry 34:15395-15406.

Eilam, Y., and W. D. Stein. 1974. Kinetic studies of transport across red blood cell membranes. Pages 283-354 in Methods in Membrane Biology. D. K. Edward, ed. Plenum Press, New York, NY.

Faulkner, A., A. J. Henderson, and M. Peaker. 1984. The effects of colchicine and vincristine on the concentrations of glucose and 
related metabolites in goat's milk. Biochim. Biophys. Acta 802:335-339.

Fell, D. A. 1992. Metabolic control analysis: A survey of its theoretical and experimental development. Biochem. J. 286:313-330.

Fisher, J. S., J. Gao, D.-H. Han, J. O. Holloszy, and L. A. Nolte. 2002. Activation of AMP kinase enhances sensitivity of muscle glucose transport to insulin. Am. J. Physiol. Endocrinol. Metab. 282:E18-E23.

Heard, K. S., N. Fidyk, and A. Carruthers. 2000. ATP-dependent substrate occlusion by the human erythrocyte sugar transporter. Biochemistry 39:3005-3014.

Helgerson, A. L., and A. Carruthers. 1989. Analysis of protein-mediated 3-O-methylglucose transport in rat erythrocytes: Rejection of the alternating conformation carrier model for sugar transport. Biochemistry 28:4580-4594.

Holt, C. 1983. Swelling of Golgi vesicles in mammary secretory cells and its relation to the yield and quantitative composition of milk. J. Theor. Biol. 101:247-261.

Hurtaud, C., H. Rulquin, and R. Verite. 1998. Effects of graded duodenal infusions of glucose on yield and composition of milk from dairy cows. 1. Diets based on corn silage. J. Dairy Sci. 81:3239-3247.

Kahn, B. B. 1992. Facilitative glucose transporters: Regulatory mechanisms and dysregulation in diabetes. J. Clin. Invest. 89:13671374 .

Klip, A. 1982. Regulation of glucose transport by insulin and nonhormonal factors. Life Sci. 31:2537-2548.

Lehoux, E. A., Z. Svedruzic, and H. O. Spivey. 1997. Determination of the specific radioactivity of $\left[{ }^{14} \mathrm{C}\right]$ lactate by enzymatic decarboxylation and ${ }^{14} \mathrm{CO}_{2}$ collection. Anal. Biochem. 253:190-195.

Leuzzi, R., R. Fulceri, P. Marcolongo, G. Banhegyi, E. Zammarchi, K. Stafford, A. Burchell, and A. Benedetti. 2001. Glucose 6-phosphate transport in fibroblast microsomes from glycogen storage disease type 1b patients: Evidence for multiple glucose 6-phosphate transport systems. Biochem. J. 357:557-562.

Lin, B., C. J. Pan, and J. Y. Chou. 2000. Human variant glucose-6phosphate transporter is active in microsomal transport. Hum. Genet. 107:526-529.

Macheda, M. L., E. D. Williams, J. D. Best, M. E. Wlodek, and S. Rogers. 2003. Expression and localisation of GLUT1 and GLUT12 glucose transporters in the pregnant and lactating rat mammary gland. Cell Tissue Res. 311:91-97.

Mepham, T. B. Physiology of Lactation. 1987. Open University Press, Philadelphia, PA.

Naftalin, R. J., and R. J. Rist. 1991. 3-O-methyl-D-glucose transport in rat red cells: Effects of heavy water. Biochim. Biophys. Acta 1064:37-48.

Naftalin, R. J., and R. J. Rist. 1989. Evidence that activation of 2deoxy-D-glucose transport in rat thymocyte suspensions results from enhanced coupling between transport and hexokinase activity. Biochem. J. 260:143-152.

Naftalin, R. J., P. M. Smith, and S. E. Roselaar. 1985. Evidence for non-uniform distribution of D-glucose within human red cells during net exit and counterflow. Biochim. Biophys. Acta 820:235-249.

Nielsen, M. O., T. G. Madsen, and A. M. Hedeboe. 2001. Regulation of mammary glucose uptake in goats: Role of mammary gland supply, insulin, IGF-1 and synthetic capacity. J. Dairy Res. 68:337-349

Perriott, L. M., T. Kono, R. R. Whitesell, S. M. Knobel, D. W. Piston, D. K. Granner, A. C. Powers, and J. M. May. 2001. Glucose uptake and metabolism by cultured human skeletal muscle cells: Ratelimiting steps. Am. J. Physiol. Endocrinol. Metab. 281:E72-E80.

Regen, D. M., and H. L. Tarpley. 1974. Anomalous transport kinetics and the glucose carrier hypothesis. Biochim. Biophys. Acta 339:218-233.

Ren, J. M., B. A. Marshall, E. A. Gulve, J. Gao, D. W. Johnson, J. O. Holloszy, and M. Mueckler. 1993. Evidence from transgenic mice that glucose transport is rate-limiting for glycogen deposition and glycolysis in skeletal muscle. J. Biol. Chem. 268:16113-16115.
Rigout, S., S. Lemosquet, E. J. Van, J. W. Blum, and H. Rulquin. 2002. Duodenal glucose increases glucose fluxes and lactose synthesis in grass silage-fed dairy cows. J. Dairy Sci. 85:595-606.

Shipley, R. A., and R. E. Clark. 1972. Tracer Methods for In Vivo Kinetics: Theory and Applications. Academic Press, New York, NY.

SAS Institute. 1999. User's Guide: Statistics, Version 8.01 edition. SAS Inst., Inc., Cary, NC.

Threadgold, L. C., H. G. Coore, and N. J. Kuhn. 1982. Monosaccharide transport into lactating-rat mammary acini. Biochem. J. 204:493-501.

Threadgold, L. C., and N. J. Kuhn. 1984. Monosaccharide transport in the mammary gland of the intact lactating rat. Biochem. J. 218:213-219.

Toerien, C. A., J. P. Cant, and C. K. Stewart. 2003. Expression of transition initiation factors in mammary glands of lactating and dry dairy cows. J. Anim. Sci. 81(Suppl. 1):301.

Wheeler, T. J., and J. D. Whelan. 1988. Infinite-cis kinetics support the carrier model for erythrocyte glucose transport. Biochemistry 27:1441-1450.

Whitesell, R. R., H. Ardehali, R. L. Printz, J. M. Beechem, S. M. Knobel, D. W. Piston, D. K. Granner, W. Van Der Meer, L. M. Perriott, and J. M. May. 2003. Control of glucose phosphorylation in L6 myotubes by compartmentalization, hexokinase, and glucose transport. Biochem. J. 370:47-56.

Widdas, W. F. 1952. Inability of diffusion to account for placental glucose transfer in the sheep and consideration of the kinetics of a possible carrier transfer. J. Physiol. 118:23-39.

Wilde, C. J., and N. J. Kuhn. 1981. Lactose synthesis and the utilization of glucose by rat mammary acini. Int. J. Biochem. 13:311-316.

Xiao, C., and J. P. Cant. 2003. Glucose transporter in bovine mammary epithelial cells is an asymmetric carrier that exhibits cooperativity and trans-stimulation. Am. J. Physiol. Cell Physiol. 285:C1226-C1234.

Xiao, C., V. M. Quinton, and J. P. Cant. 2004. Description of glucose transport in isolated bovine mammary epithelial cells by a 3compartment model. Am. J. Physiol. Cell Physiol. 286:C792C797.

Zhao, F. Q., W. T. Dixon, and J. J. Kennelly. 1996. Localization and gene expression of glucose transporters in bovine mammary gland. Comp. Biochem. Physiol. B Biochem. Mol. Biol. 115:127-134.

Zhao, F. Q., E. K. Okine, and J. J. Kennelly. 1999. Glucose transporter gene expression in bovine mammary gland. J. Anim. Sci. $77: 2517-2522$.

\section{APPENDIX}

Mathematical description of the model shown in Figure 7.

Extracellular glucose pool, GlE (nmol)

$\mathrm{U}_{\mathrm{OE}}=\mathrm{V}_{\mathrm{GlEGIO}} /\left[1+\mathrm{K}_{\mathrm{GlEGlO}} /(\mathrm{GlO})\right]$

$\mathrm{U}_{\mathrm{EO}}=\mathrm{V}_{\mathrm{GlEGIO}} /\left[1+\mathrm{K}_{\mathrm{GlEGlO}} /(\mathrm{GlE})\right]$

$\mathrm{dGlE} / \mathrm{dt}=\mathrm{U}_{\mathrm{OE}}-\mathrm{U}_{\mathrm{EO}}$

$[\mathrm{GlE}]=\mathrm{GlE} / \mathrm{evol}$

Occluded glucose pool, GlO (nmol)

$\mathrm{U}_{\mathrm{IO}}=\mathrm{k}_{\mathrm{GIIGIO}}$ GlI

$\mathrm{U}_{\mathrm{OI}}=\mathrm{k}_{\mathrm{GlOGII}} \mathrm{GlO}$

$\mathrm{U}_{\mathrm{GlOLac}}=\mathrm{U}_{\mathrm{G} 1 \mathrm{PLac}}$

$\mathrm{U}_{\mathrm{GlOG} 6 \mathrm{P}}=\mathrm{V}_{\mathrm{GlOG} 6 \mathrm{P}} /\left[1+\mathrm{K}_{\mathrm{GlOG} 6 \mathrm{P}} /(\mathrm{GlO})\right]$

$\mathrm{dGlO} / \mathrm{dt}=\mathrm{U}_{\mathrm{EO}}-\mathrm{U}_{\mathrm{OE}}+\mathrm{U}_{\mathrm{IO}}-\mathrm{U}_{\mathrm{OI}}-\mathrm{U}_{\mathrm{GlOG} 6 \mathrm{P}}$

$-\mathrm{U}_{\mathrm{GlOLac}}$

$[\mathrm{GlO}]=\mathrm{GlO} / \mathrm{ovol}$ 
Intracellular glucose pool, GlI (nmol) $\mathrm{dGII} / \mathrm{dt}=\mathrm{U}_{\mathrm{OI}}-\mathrm{U}_{\mathrm{IO}}$ $[\mathrm{GlI}]=\mathrm{GlI} / \mathrm{ivol}$

G6P pool, G6P (nmol) $\mathrm{U}_{\mathrm{G} 6 \mathrm{PCO} 2}=\mathrm{V}_{\mathrm{G} 6 \mathrm{PCO} 2} /\left[1+\mathrm{K}_{\mathrm{G} 6 \mathrm{PCO} 2} /(\mathrm{G} 6 \mathrm{P})\right]$

$\mathrm{U}_{\mathrm{G} 6 \mathrm{PG} 1 \mathrm{P}}=\mathrm{k}_{\mathrm{G} 6 \mathrm{PG} 1 \mathrm{P}} \mathrm{G} 6 \mathrm{P}$

$\mathrm{dG} 6 \mathrm{P} / \mathrm{dt}=\mathrm{U}_{\mathrm{GlOG} 6 \mathrm{P}}-\mathrm{U}_{\mathrm{G} 6 \mathrm{PG} 1 \mathrm{P}}-\mathrm{U}_{\mathrm{G} 6 \mathrm{PCO} 2}$
$[11] \quad[\mathrm{G} 6 \mathrm{P}]=\mathrm{G} 6 \mathrm{P} /($ ovol $+\mathrm{ivol})$
[12] G1P pool, G1P (nmol)
$\mathrm{U}_{\mathrm{G} 1 \mathrm{PLac}}=\mathrm{V}_{\mathrm{G} 1 \mathrm{PLad}} /\left[1+\mathrm{K}_{\mathrm{G} 1 \mathrm{PLad}} /(\mathrm{G} 1 \mathrm{P})\right]$
[13] $\quad \mathrm{U}_{\mathrm{G1PG6P}}=\mathrm{k}_{\mathrm{G} 1 \mathrm{PG} 6 \mathrm{P}} \mathrm{G} 1 \mathrm{P}$
[14] $\mathrm{dG1P} / \mathrm{dt}=\mathrm{U}_{\mathrm{G} 6 \mathrm{PG} 1 \mathrm{P}}-\mathrm{U}_{\mathrm{G} 1 \mathrm{PG} 6 \mathrm{P}}-\mathrm{U}_{\mathrm{G} 1 \mathrm{PLac}}$ $[\mathrm{G} 1 \mathrm{P}]=\mathrm{G} 1 \mathrm{P} /($ ovol + ivol $)$

